\title{
Investigation of cause-specific mortality rates of European Union member and candidate countries by World Health Organization global health estimate categories
}

\author{
Deniz Sığırıı®, Sultan Kılıçarslan²๑ \\ ${ }^{1}$ Department of Biostatistics, Bursa Uludă̆ University Faculty of Medicine, Bursa, Turkey; ${ }^{2}$ Department of Biostatistics, Bursa Uludag \\ University Institute of Health Sciences, Bursa, Turkey
}

\begin{abstract}
Objectives: It is aimed to examine the position of our country and the European Union member and candidate countries in terms of mortality rates according to the motality causes defined in global health estimate categories determined by the World Health Organization and to reveal the similarities or differences.

Methods: According to the World Health Organization global health estimate categories given in the Global Burden of Disease 2019 study of World Health Organization, age-standardized mortality rates per 100,000 population were obtained for a total of 31 European Union member and candidate countries, and the muldimensional scaling analysis performed groups of the countries according to their dimensions obtained from multidimensional scale were determined and among these groups comparisons have been made.

Results: As a result of applying multidimensional scaling analysis, it was seen that countries can be represented in two-dimensional space according to the variables of interest.

Conclusions: It has been observed that our country differs from countries with cardiovascular diseases in the first dimension from the World Health Organization categories, while in the second dimension, infectious and parasitic diseases differ from countries with high standardized mortality rates.

Keywords: Multidimensional scaling, World Health Organization, global health estimate categories, Euclidean distance
\end{abstract}

G lobal, regional and country statistics on population and health indicators are critical for assessing development and health progress and guiding resource allocation [1]. Knowing the causes of death is important for the continuity of both preventive and curative services [2]. Understanding the causes of death of people enabling an effective response to changing epidemiological conditions, reducing preventable deaths and adapting health systems to respond effectively; will help improve health services in every country. This is as in the health policy of coun- tries; it will guide the policies and resource allocations to be followed in different sectors such as transportation, food and agriculture.

The main cause of death is defined as the disease or injury that directly initiates the process resulting in death $[3,4]$. The World Health Organization (WHO) is grouped the causes of death and disability into three large categories: communicable (infectious diseases, along with maternal, perinatal and nutritional conditions), noncommunicable (chronic diseases) and injuries. The sub-categories also have been given [1]. 
Statistics of deaths by cause are reported annually to WHO by country, year, age and sex. These statistics are available from the WHO Mortality Database [5]. Societies may differ in terms of various characteristics that may affect mortality. Age distribution is one of the most important features [6]. For this reason, it is important to use standardized criteria, especially according to age and gender, when comparing countries, regions, etc. When Turkey's death statistics are analyzed according to their causes, circulatory system diseases took the first place with $36.8 \%$ in 2019 . This cause of death was followed by benign and malignant tumors with $18.4 \%$ and respiratory system diseases with $12.9 \%$ [7].

In this study, with multidimensional scaling analysis, it is investigated how the European Union member and candidate countries are grouped according to different dimensions of cause-related mortality rates and from which variables the differences between these groups arise. In this direction, in this study, it is aimed to evaluate the current situation of Turkey among other countries in terms of cause-specific mortality rates.

\section{METHODS}

Multidimensional scaling (MDS) is a statistical analysis method used to classify objects or units by identifying similarities and differences with the help of various distance measures $[8,9]$. MDS analysis is a graphical method that helps to obtain the representation of objects or units in a space consisting of an appropriate number of dimensions, using distances calculated by various techniques depending on the variables included in the analysis. Thus, it helps to determine the relationships between both units and variables [10]. It is a method that can be applied in many fields such as health sciences, social sciences, educational sciences, marketing research [11-13]. For example, MDS analysis was used to group patients with similar diagnoses in psychiatry according to their similarities and evaluate the course of the disease according to the disease groups determined [14]. Rouzier et al. [15] used multidimensional scaling analysis in their study where they suggested that the molecular classification of breast cancer be made based on the gene structures of human tumors.

Depending on the type of data, metric and non- metric scaling techniques are used in MDS analysis. While the metric MDS technique is used for data measured with the least interval scale, the non-metric MDS technique should be applied for data measured with an ordinal scale [16-19]. Observational differences and compatibility of distances are evaluated with Shepard diagram and $\mathrm{R}^{2}$ value. The Shepard diagram shows the relationship between the observed distances and the configuration distances obtained by the MDS analysis $[11,16-18]$. $\mathrm{A} \mathrm{R}^{2}$ value of $\geq 0.60$ indicates a good fit [20].

In the MDS analysis, the stress value (i.e. the measure of correspondence between the original distances and the display distances), which is an expression of the difference between the multidimensional ( $p$-dimensional) real shape and the predicted shape in reduced (k-dimensional) space, is calculated. The stress value is given in Equation (1) [20]. It is desirable that the stress value be close to zero [20-22].

$$
\text { Stress }=\sqrt{\frac{\sum \sum\left(d_{i j}-\hat{d}_{i j}\right)^{2}}{\sum\left(d_{i j}\right)^{2}}}
$$

$d_{i j}:$ i. and j. configuration distance between individuals

$\hat{d}_{i j}$ : i. and $\mathrm{j}$. defined as the data distance between individuals.

A low stress rate indicates that the MDS solution is appropriate. A high value indicates a bad fit. The fitness values corresponding to the stress value presented by Kruskal in 1964 are given in Table 1 [14, 20, 23, 24].

Generally, two or at most three dimensions are preferred for dimension selection in MDS analysis. The number of dimensions is decided according to the stress value, $\mathrm{R}^{2}$ value, Shepard diagram [25-28].

There are various measures of distance and similarity that are used in calculating distances in MDS. These

\begin{tabular}{lc}
\multicolumn{2}{l}{ Table 1. Interpretation of the stress value } \\
\hline Stress value & Compatibility \\
\hline$\leq 0.20$ & Incompatible display \\
$0.10-<0.20$ & Low fit \\
$0.05-<0.10$ & Good fit \\
$0.025-<0.05$ & Perfect fit \\
$0.00-<0.025$ & Complete fit \\
\hline
\end{tabular}


can be listed as follows;

a) Euclidean (Euclidean) Distance Measure

In a p-variable structure $i$. and $\mathrm{j}$. The euclidean distance between the observations is as follows.

It is one of the most commonly used distance measures.

$$
d_{i j=} \sqrt{\sum_{k=1}^{p}\left(x_{i k-} x_{j k}\right)^{2}}
$$

$x_{i k}$ : i. observation $\mathrm{k}$. variable value,

$x_{j k}: \mathrm{j}$. observation $\mathrm{k}$. variable value,

$\mathrm{p}$ : the number of variables.

Square Euclidean (Square Euclidean) measure of distance

$$
d_{i j}=\sum_{k=1}^{p}\left(x_{i k-} x_{j k}\right)^{2}
$$

a) Chebychev distance measure

$$
d_{i j}=\max _{k}^{p}\left|x_{i k^{-}} x_{j k}\right|
$$

b) Manhattan City-Block distance measure

$$
d_{i j=} \sum_{k=1}^{p}\left|x_{i k}-x_{j k}\right|(5)
$$

c) Minkowski distance measure $\mathrm{m}=1$ için Manhattan City-Block measure of distance, $\mathrm{m}=2$ için returns the measure of Euclidean distance. As $\mathrm{m}$ increases, the distance approaches the Chebychev distance measure.

$$
d_{i j}=\left[\sum_{k=1}^{p}\left|x_{i k}-x_{j k}\right|^{m}\right]^{\frac{1}{m}}
$$

a) Karl Pearson distance measure/ Standardized Measure of Euclidean Distance is in the form [11].

$$
d_{i j}=\sqrt{\sum_{k=1}^{p} \frac{1}{s_{k}{ }^{2}}\left(x_{i k}-x_{j k}\right)^{2}}
$$

In this study, age-standardized cause-related mortality rates were taken. Causes of death categories were made according to the Global Health Estimates (GHE) classification in the 2019 World Health Report and are given in Table $2[1,2]$. In case of missing data for one or more countries in the sub-categories, the parent category to which that sub-category belongs was taken into account (Table 2). Euclidean distance was used in the determination of the distance matrix in the MDS. These data are has been obtained from 31 countries European Union members Germany, Austria, Belgium, Bulgaria, France, France, Netherlands, Finland, Ireland, France, Sweden, Italy, Cyprus, Let, Lithuania, Luxembourg, Hungary, Malta, Poland, Portugal, Romania, Slovakia, Slovenia, Greece and candidate countries Albania, Macedonia, Serbia and Turkey. Candidate country Montenegro was not in-

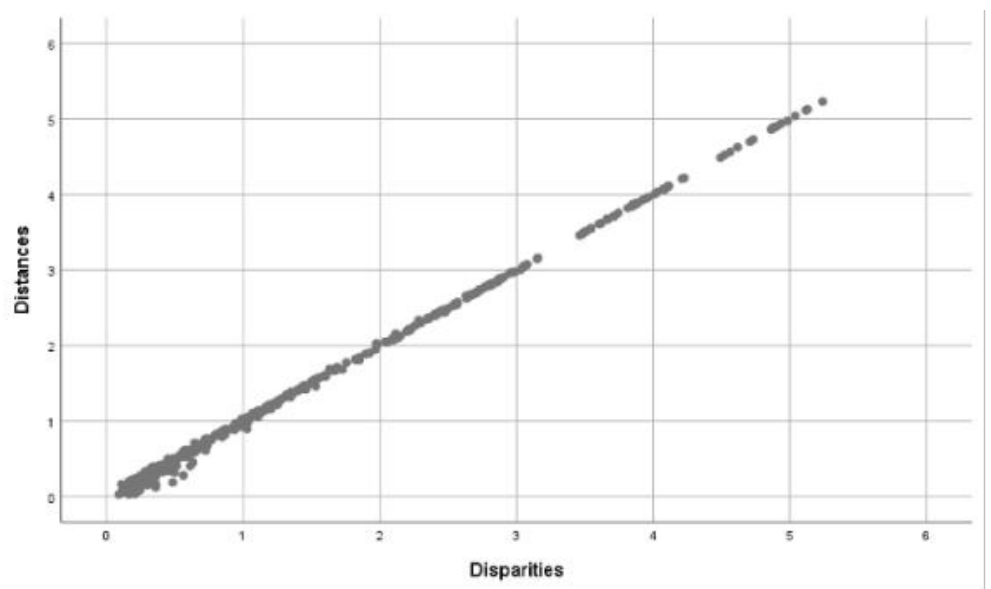

Fig. 1. Shepard diagram for observed distances and configuration distances 
Table 2. Global health estimate cause categories and ICD-10 codes

\begin{tabular}{|c|c|c|}
\hline GHE code & GHE cause & ICD-10 code \\
\hline 0 & All causes & \\
\hline 10 & \multicolumn{2}{|c|}{ I. Communicable, maternal, perinatal and nutritional conditions } \\
\hline 20 & I.A Infectious and parasitic diseases & A00-B99, G00-G04, G14, N70-N73, P37.3, P37.4 \\
\hline 380 & I.B. Respiratory Infectious & H65-H66, J00-J22, P23, U04 \\
\hline 420 & I.C. Maternal conditions & O00-099 \\
\hline 490 & I.D. Neonatal conditions & P00-P96 (minus P23, P37.3, P37.4) \\
\hline 540 & I.E. Nutritional deficiencies & D50-D53, D64.9, E00-E02, E40-E46, E50-E64 \\
\hline 600 & \multicolumn{2}{|l|}{ II. Noncommunicable diseases ${ }^{\#}$} \\
\hline 610 & II.A. Malignant neoplasms & $\mathrm{C} 00-\mathrm{C} 97$ \\
\hline 620 & 1. Mouth and oropharynx cancers & $\mathrm{C} 00-\mathrm{C} 14$ \\
\hline 630 & 2. Oesophagus cancer & $\mathrm{C} 15$ \\
\hline 640 & 3. Stomach cancer & $\mathrm{C} 16$ \\
\hline 650 & 4. Colon and rectum cancers & $\mathrm{C} 18-\mathrm{C} 21$ \\
\hline 660 & 5. Liver cancer & $\mathrm{C} 22$ \\
\hline 670 & 6. Pancreas cancer & $\mathrm{C} 25$ \\
\hline 680 & 7. Trachea, bronchus, lung cancers & $\mathrm{C} 33-\mathrm{C} 34$ \\
\hline 690 & 8. Melanoma and other skin cancers & $\mathrm{C} 43-\mathrm{C} 44$ \\
\hline 700 & 9. Breast cancer & $\mathrm{C} 50$ \\
\hline 710 & 10. Cervix uteri cancer & $\mathrm{C} 53$ \\
\hline 720 & 11. Corpus uteri cancer & $\mathrm{C} 54$ \\
\hline 730 & 12. Ovary cancer & $\mathrm{C} 56$ \\
\hline 740 & 13. Prostate cancer & C61 \\
\hline 742 & 14. Testicular cancer* & C62 \\
\hline 745 & 15. Kidney cancer & C64-C66 \\
\hline 750 & 16. Bladder cancer & C67 \\
\hline 751 & 17. Brain and nervous system cancers & $\mathrm{C} 70-\mathrm{C} 72$ \\
\hline 752 & 18. Gallbladder and biliary tract cancer & $\mathrm{C} 23-\mathrm{C} 24$ \\
\hline 753 & 19. Larynx cancer & $\mathrm{C} 32$ \\
\hline 754 & 20. Thyroid cancer & $\mathrm{C} 73$ \\
\hline 755 & 21. Mesothelioma & $\mathrm{C} 45$ \\
\hline 760 & 22. Lymphomas, multiple myeloma & C81-C90, C96 \\
\hline 770 & 23. Leukaemia & C91-C95 \\
\hline 780 & 24. Other malignant neoplasms* & $\begin{array}{c}\mathrm{C} 17, \mathrm{C} 26-\mathrm{C} 31, \mathrm{C} 37-\mathrm{C} 41, \mathrm{C} 46-\mathrm{C} 49, \mathrm{C} 51, \mathrm{C} 52, \mathrm{C} 57-\mathrm{C} 60, \mathrm{C} 63, \\
\text { C68, C69, C74-C75, C77-C } 79\end{array}$ \\
\hline 790 & II.B. Other neoplasms* & D00-D48 \\
\hline 800 & II.C. Diabetes mellitus & E10-E14 (minus E10.2, E11.2, E12.2, E13.2, E14.2) \\
\hline 810 & II.D. Endocrine, blood, immune disorders & $\begin{array}{l}\text { D55-D64 (minus D64.9), D65-D89, E03-E07, E15-E34, E65- } \\
\text { E88 }\end{array}$ \\
\hline 820 & II.E. Mental and substance use disorders & F04-F99, G72.1, Q86.0, X41-X42, X44, X45 \\
\hline 940 & II.F. Neurological conditions & F01-F03, G06-G98 (minus G14, G72.1) \\
\hline 1020 & II.G. Sense organ diseases* & H00-H61, H68-H93 \\
\hline 1100 & II.H. Cardiovascular diseases & I00-I99 \\
\hline 1170 & II.I. Respiratory diseases & J30-J98 \\
\hline 1210 & II.J. Digestive diseases & K20-K92 \\
\hline 1260 & II.K. Genitourinary diseases & $\begin{array}{c}\text { E10.2-E10.29,E11.2-E11.29,E12.2,E13.2-E13.29,E14.2, N00- } \\
\text { N64, N75-N76, N80-N98 }\end{array}$ \\
\hline 1330 & II.L. Skin diseases & L00-L98 \\
\hline 1340 & II.M. Musculoskeletal diseases & M00-M99 \\
\hline 1400 & II.N. Congenital anomalies & Q00-Q99 (minus Q86.0) \\
\hline 1470 & II.O. Oral conditions * & $\mathrm{K} 00-\mathrm{K} 14$ \\
\hline 1505 & II.P. Sudden infant death syndrome & R95 \\
\hline 1510 & III. Injuries $\#$ & \\
\hline 1520 & III.A. Unintentional injuries & V01-X40, X43, X46-59, Y40-Y86, Y88, Y89 \\
\hline 1600 & III.B. Intentional injuries & $\mathrm{X} 60-\mathrm{Y} 09, \mathrm{Y} 35-\mathrm{Y} 36, \mathrm{Y} 870, \mathrm{Y} 871$ \\
\hline
\end{tabular}

\# Subcategories included, ${ }^{*}$ Could not include due to lack of data.

GHE $=$ Global health estimate cause categories defined in "WHO methods and data sources for country-level causes of death 2000-2019. (Global Health Estimates Technical Paper WHO/DDI/DNA/GHE/2020.2). Geneva, World Health Organization; 2020." [1] 


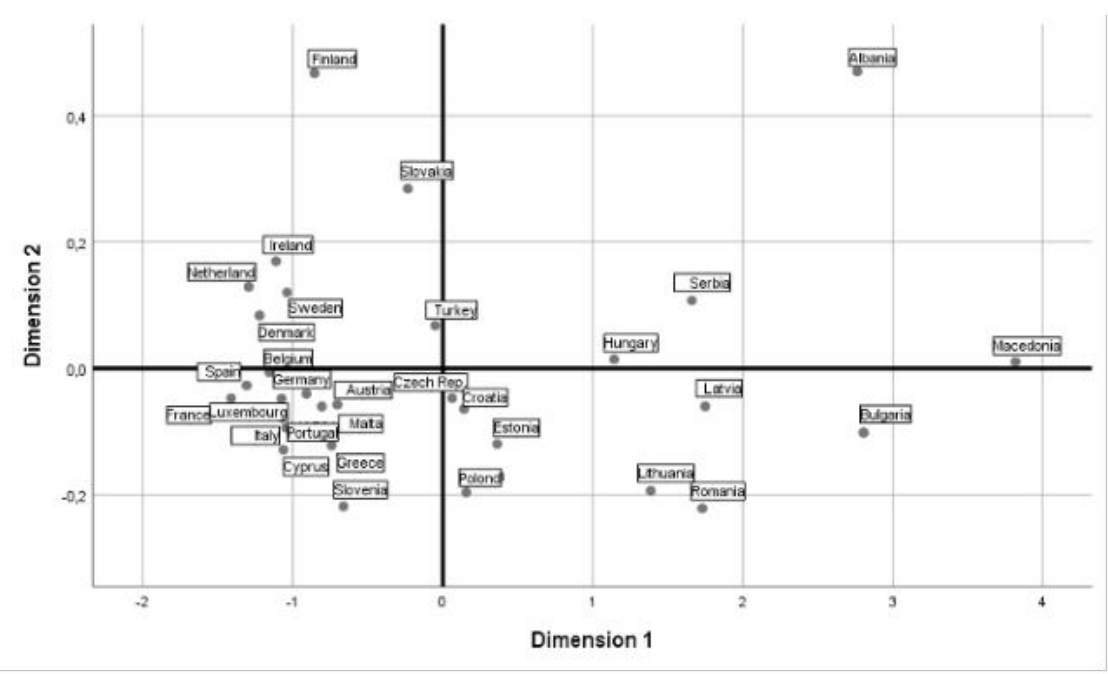

Fig. 2. Graph of the Euclidean distance model

cluded in the study due to lack of data.

\section{Statistical Analysis}

IBM Statistics SPSS for Windows v. 25.0 package program was used. The significance level was accepted as $\alpha=0.05$. According to the analysis results obtained, the Kruskall stress statistic was found to be 0.022 for the $r=2$ dimension. Accordingly, we can say that 2 dimensional scaling adequately reflects the data set we have. The Shepard graph showing the observed distances and the distribution of the configuration distances was found as in Fig. 1. The $\mathrm{R}^{2}$ value is 0.99 . Accordingly, it has been determined that there is a linear relationship between two different distance values and that a suitable solution can be presented with a linear model to the data. The positions of each country relative to each other in terms of cause-specific mortality rates selected by WHO are given in the two-dimensional graph of the Euclidean distance model in Fig. 2. Germany, Austria, Belgium, Czechia, Den-

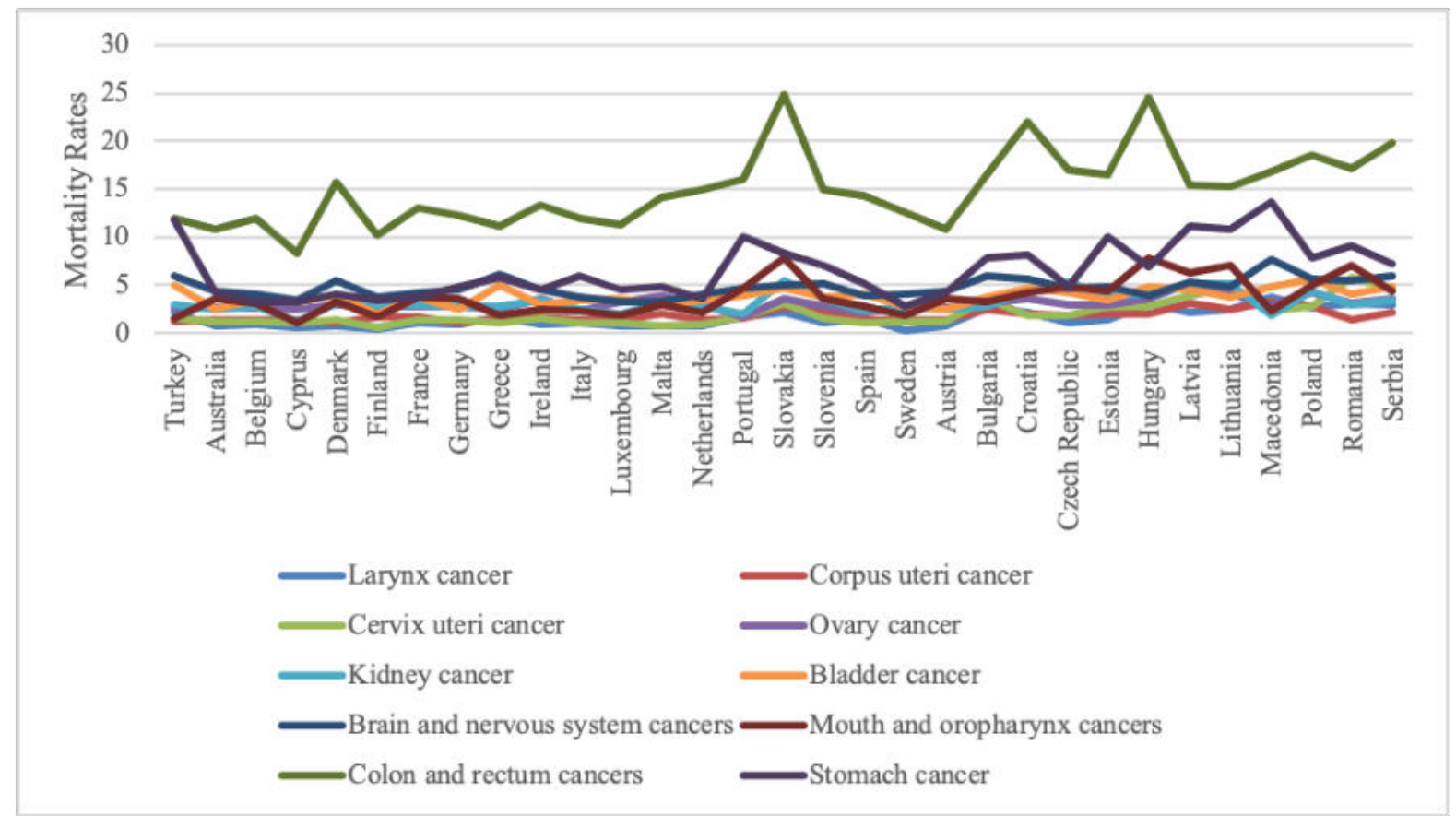

Fig. 3. Distribution of mortality rates of countries according to cancer types which are found significant according fo first dimension 
Table 3. Comparison of variables according to the first dimension

\begin{tabular}{|c|c|c|c|}
\hline Cause of death categories & $\mathbf{x}<\mathbf{0}$ & $\mathbf{x}>\mathbf{0}$ & $p$ - value \\
\hline Infectious and parasitic diseases & $6.40(1.90-17.50)$ & $6.35(2.70-12.70)$ & 0.968 \\
\hline Respiratory infectious & $8.40(2.80-20.30)$ & $10.85(5.60-26.30)$ & 0.311 \\
\hline Maternal conditions & $0.10(0.00-0.10)$ & $0.10(0.00-0.30)$ & 0.115 \\
\hline Neonatal conditions & $2.40(1.30-6.20)$ & $2.60(1.30-6.60)$ & 0.556 \\
\hline Nutritional deficiencies & $0.70(0.00-1.90)$ & $0.35(0.10-1.30)$ & 0.061 \\
\hline Mouth and oropharynx cancers & $2.70(1.10-7.90)$ & $4.60(1.90-7.90)$ & 0.004 \\
\hline Oesophagus cancer & $2.50(0.50-5.80)$ & $2.45(1.00-4.20)$ & 0.871 \\
\hline Stomach cancer & $4.50(2.70-11.70)$ & $8.65(4.80-13.70)$ & 0.001 \\
\hline Colon and rectum cancers & $12.50(8.30-24.90)$ & $16.90(4.30-24.50)$ & 0.001 \\
\hline Liver cancer & $4.50(3.20-6.70)$ & $4.35(3.10-9.00)$ & 0.382 \\
\hline Pancreas cancer & $7.80(5.50-9.50)$ & $8.10(4.80-10.40)$ & 0.291 \\
\hline Trachea, bronchus, lung cancers & $24.80(16.10-39.70)$ & $26.15(21.50-43.50)$ & 0.156 \\
\hline Melanoma and other skin cancers & $2.10(1.50-3.90)$ & $2.80(1.40-4.00)$ & 0.059 \\
\hline Breast cancer & $9.90(6.40-11.00)$ & $10.75(5.50-14.20)$ & 0.024 \\
\hline Cervix uteri cancer & $1.20(0.60-3.10)$ & $2.80(1.10-5.80)$ & $<0.001$ \\
\hline Corpus uteri cancer & $1.40(1.10-2.80)$ & $2.10(0.90-3.30)$ & 0.004 \\
\hline Ovary cancer & $2.70(1.70-3.90)$ & $3.30(0.90-5.20)$ & 0.009 \\
\hline Prostate cancer & $6.00(3.90-9.50)$ & $7.10(5.40-8.90)$ & 0.155 \\
\hline Kidney cancer & $2.80(1.20-5.50)$ & $4.00(1.90-5.30)$ & $\mathbf{0 . 0 3 3}$ \\
\hline Bladder cancer & $3.50(2.00-5.00)$ & $4.55(3.40-6.60)$ & 0.003 \\
\hline Brain and nervous system cancers & $4.20(3.20-6.10)$ & $5.55(3.90-7.70)$ & 0.004 \\
\hline Gallbladder and biliary tract cancer & $1.30(0.60-3.80)$ & $2.15(0.90-3.30)$ & 0.053 \\
\hline Larynx cancer & $0.90(0.30-2.20)$ & $2.55(1.10-3.70)$ & $<0.001$ \\
\hline Thyroid cancer & $0.40(0.30-2.20)$ & $0.40(0.30-0.60)$ & 0.180 \\
\hline Mesothelioma & $0.70(0.20-1.50)$ & $0.20(0.00-0.90)$ & $<0.001$ \\
\hline Lymphomas, multiple myeloma & $5.60(4.70-9.00)$ & $5.30(1.60-6.80)$ & 0.046 \\
\hline Leukaemia & $4.20(2.80-5.60)$ & $4.50(3.30-4.90)$ & 0.556 \\
\hline Diabetes mellitus & $6.50(3.50-20.10)$ & $10.80(4.20-32.60)$ & 0.081 \\
\hline Endocrine, blood, immune disorders & $3.90(1.90-5.90)$ & $1.65(0.50-3.50)$ & $<0.001$ \\
\hline Mental and substance use disorders & $4.60(1.30-14.60)$ & $4.60(0.80-13.80)$ & 0.823 \\
\hline Neurological conditions & $28.20(14.80-66.10)$ & $17.95(6.50-48.10)$ & 0.001 \\
\hline Cardiovascular diseases & $96.50(68.90-173.50)$ & $295.25(182.30-470.60)$ & $<0.001$ \\
\hline Respiratory diseases & $22.90(11.90-35)$ & $21.85(9.40-37.70)$ & 0.968 \\
\hline Digestive Diseases & $16.10(11.10-33.80)$ & $28.50(14.10-45.00)$ & $<0.001$ \\
\hline Genitourinary Diseases & $8.80(2.40-20.50)$ & $9.50(5.80-23.00)$ & 0.516 \\
\hline Skin diseases & $0.60(0.10-1.80)$ & $0.60(0.00-1.50)$ & 0.553 \\
\hline Musculoskeletal Diseases & $1.80(0.90-3.00)$ & $1.20(0.20-2.40)$ & 0.047 \\
\hline Congenital anomalies & $2.80(1.40-6.00)$ & $2.85(1.80-4.40)$ & 0.984 \\
\hline Sudden infant death syndrome & $0.20(0.00-0.40)$ & $0.15(0.10-0.40)$ & 0.847 \\
\hline Unintentional injuries & $16.60(10.40-29.70)$ & $21.55(13.40-35.30)$ & 0.002 \\
\hline Intentional injuries & $9.10(4.30-15.10)$ & $10.00(7.00-24.40)$ & 0.282 \\
\hline
\end{tabular}


Table 4. Comparison of variables according to the second dimension

\begin{tabular}{|c|c|c|c|}
\hline Cause of death categories & $\mathrm{y}<\mathbf{0}$ & $\mathbf{y}>\mathbf{0}$ & $p$-value \\
\hline Infectious and parasitic diseases & $7.00(1.90-17.50)$ & $4.00(2.20-7.90)$ & 0.022 \\
\hline Respiratory infectious & $10.60(4.30-26.30)$ & $10.50(2.80-20.30)$ & 0.726 \\
\hline Maternal conditions & $0.10(0.00-0.30)$ & $0.10(0.00-0.20)$ & 0.783 \\
\hline Neonatal conditions & $2.30(1.30-4.70)$ & $3.00(1.30-6.60)$ & 0.103 \\
\hline Nutritional deficiencies & $0.50(0.00-1.90)$ & $0.40(0.10-1.00)$ & 0.507 \\
\hline Mouth and oropharynx cancers & $3.55(1.10-7.10)$ & $2.30(1.50-7.90)$ & 0.173 \\
\hline Oesophagus cancer & $2.45(0.50-4.20)$ & $2.50(1.00-5.80)$ & 0.695 \\
\hline Stomach cancer & $5.90(3.30-11.20)$ & $6.80(2.70-13.70)$ & 0.918 \\
\hline Colon and rectum cancers & $14.60(8.30-22.10)$ & $15.00(4.30-24.90)$ & 0.710 \\
\hline Liver cancer & $4.50(3.10-8.30)$ & $4.20(3.20-9.00)$ & 0.804 \\
\hline Pancreas cancer & $7.80(5.50-10.30)$ & $8.00(4.80-10.40)$ & 0.741 \\
\hline Trachea, bronchus, lung cancers & $23.80(16.60-34.90)$ & $28.80(16.10-43.50)$ & 0.215 \\
\hline Melanoma and other skin cancers & $2.20(1.50-3.90)$ & $2.90(1.40-4.00)$ & 0.086 \\
\hline Breast cancer & $9.90(6.90-11.50)$ & $10.10(5.50-14.20)$ & 0.820 \\
\hline Cervix uteri cancer & $1.45(0.70-5.80)$ & $1.50(0.60-4.60)$ & 0.918 \\
\hline Corpus uteri cancer & $1.55(1.10-3.10)$ & $1.60(0.90-3.30)$ & 0.663 \\
\hline Ovary cancer & $2.90(1.70-5.20)$ & $2.90(0.90-3.60)$ & 0.852 \\
\hline Prostate cancer & $5.80(3.90-8.90)$ & $6.80(5.70-9.50)$ & 0.039 \\
\hline Kidney cancer & $2.85(1.20-5.30)$ & $3.00(1.90-5.50)$ & 0.710 \\
\hline Bladder cancer & $3.75(2.50-5.60)$ & $4.60(2.00-6.60)$ & 0.374 \\
\hline Brain and nervous system cancers & $4.70(3.20-6.10)$ & $5.00(3.80-7.70)$ & 0.374 \\
\hline Gallbladder and biliary tract cancer & $1.30(0.60-3.30)$ & $1.40(0.70-3.80)$ & 0.320 \\
\hline Larynx cancer & $1.20(0.50-3.10)$ & $2.00(0.30-3.70)$ & 0.984 \\
\hline Thyroid cancer & $0.40(0.30-0.60)$ & $0.40(0.30-0.90)$ & 0.692 \\
\hline Mesothelioma & $0.55(0.10-1.10)$ & $0.40(0.00-1.50)$ & 0.559 \\
\hline Lymphomas, multiple myeloma & $5.60(3.80-9.00)$ & $5.30(1.60-7.40)$ & 0.663 \\
\hline Leukaemia & $4.35(3.10-5.00)$ & $4.10(2.80-5.60)$ & 0.508 \\
\hline Diabetes mellitus & $7.95(4.20-16.50)$ & $7.40(3.50-32.60)$ & 0.853 \\
\hline Endocrine, blood, immune disorders & $3.05(0.60-5.90)$ & $3.00(0.50-4.40)$ & 0.353 \\
\hline Mental and substance use disorders & $4.90(1.40-14.60)$ & $4.10(0.80-11.00)$ & 0.509 \\
\hline Neurological conditions & $23.05(6.50-34.50)$ & $40.40(9.60-66.10)$ & 0.003 \\
\hline Cardiovascular diseases & $121.85(68.90-393.80)$ & $160.20(79.10-470.60)$ & 0.741 \\
\hline Respiratory diseases & $20.35(9.40-37.70)$ & $30.10(11.90-35.60)$ & 0.052 \\
\hline Digestive Diseases & $19.15(11.10-45.00)$ & $16.20(11.70-34.60)$ & 0.364 \\
\hline Genitourinary Diseases & $9.65(3.80-15.40)$ & $8.40(2.40-23.00)$ & 0.901 \\
\hline Skin diseases & $0.60(0.10-1.80)$ & $0.60(0.00-1.60)$ & 0.289 \\
\hline Musculoskeletal Diseases & $1.75(0.20-3.00)$ & $1.50(0.20-2.70)$ & 0.725 \\
\hline Congenital anomalies & $2.60(1.40-5.00)$ & $3.20(2.00-6.00)$ & 0.148 \\
\hline Sudden infant death syndrome & $0.20(0.00-0.40)$ & $0.20(0.00-0.40)$ & 0.646 \\
\hline Unintentional injuries & $19.05(11.00-35.30)$ & $15.60(10.40-29.70)$ & 0.098 \\
\hline Intentional injuries & $9.55(4.30-24.40)$ & $9.70(7.00-14.50)$ & 0.934 \\
\hline
\end{tabular}




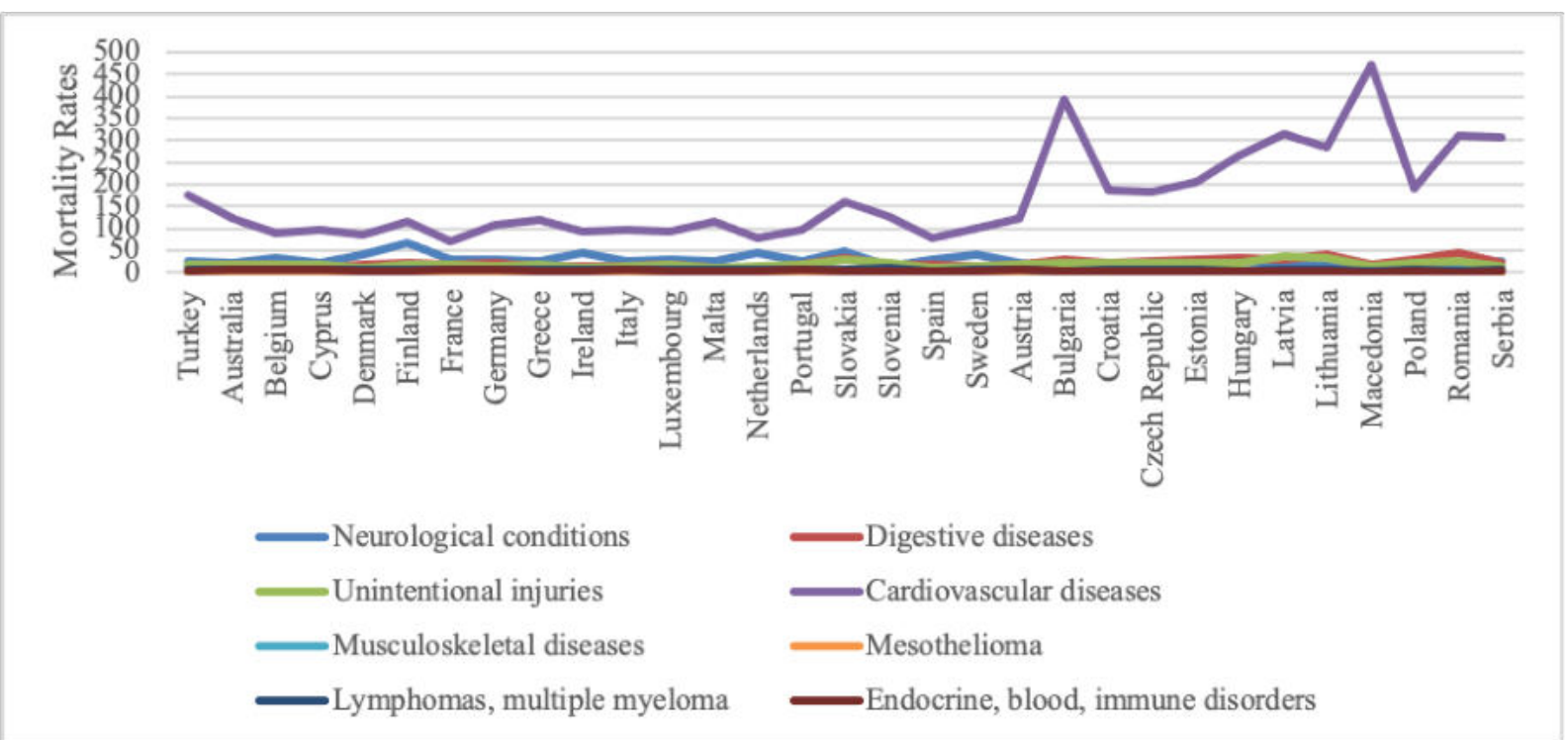

Fig. 4. Distribution of mortality rates of countries according to other causes of death which are found significant according to first dimension.

mark, France, Netherlands, Ireland, Spain, Sweden, Italy, Cyprus, Luxembourg, Malta, Portugal and Greece, which are close to each other in both dimensions, form a group; it has been observed that Turkey is close to these countries in terms of both dimensions.

\section{RESULTS}

According to the first dimension, the countries were divided into two groups according to the $0 \mathrm{ab}$ - scissa, and the differences between the groups were analyzed according to the causes of death examined. Accordingly, the groups in the first dimension include cancers of the mouth and oropharynx, stomach, colon and rectum, breast, cervix, uterus, ovary, kidney, bladder, brain and nervous system, laryngeal cancers, cardiovascular diseases, digestive diseases, mesothelioma, lymphoma and multiple myelomas, endocrine, blood and immunity diseases, neurological disorders, musculoskeletal system diseases and unintentional injuries statistically significant difference

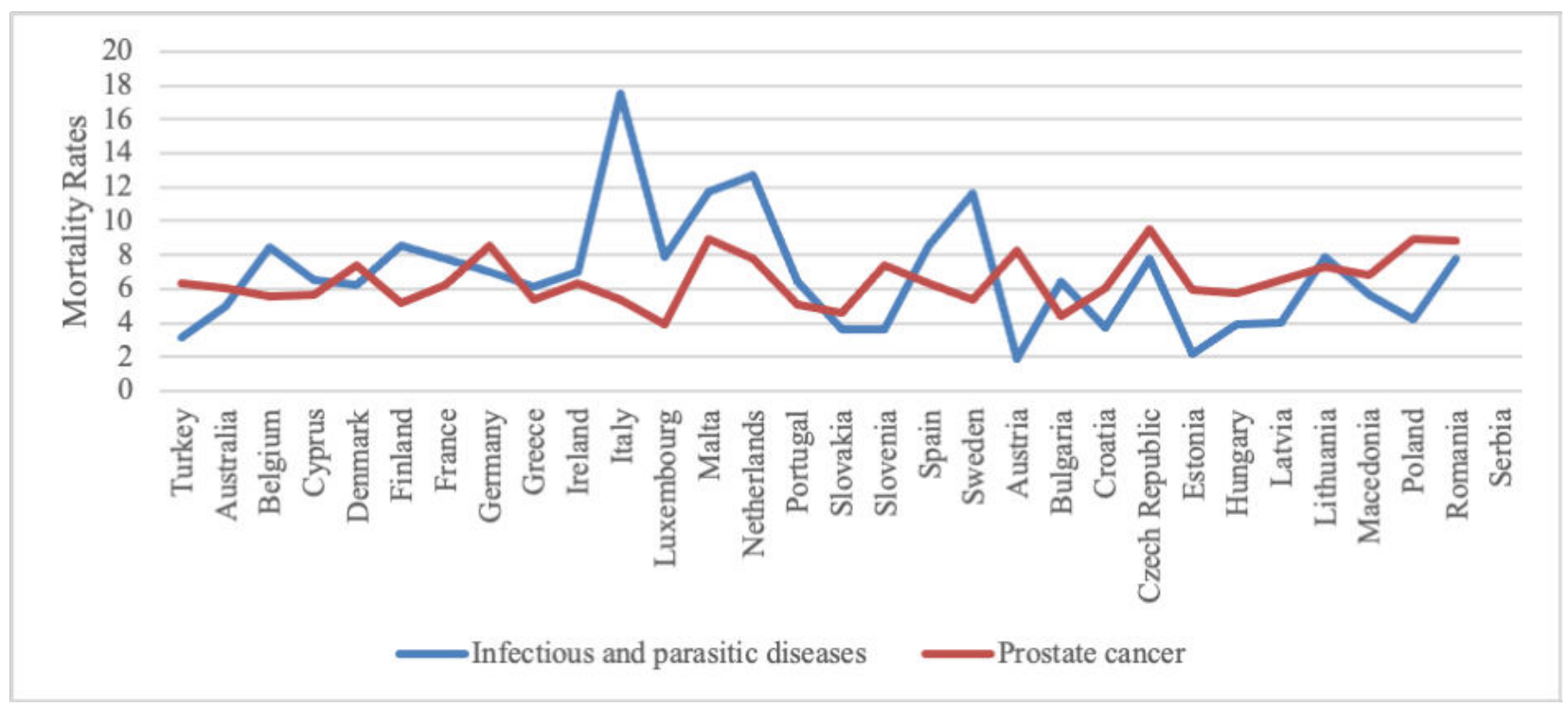

Fig. 5. Distribution of mortality rates of countries according to causes of death which are found significant according to second dimension. 
was found in terms of mortality rates due to (Table 3 , Fig. 3).

According to the second dimension, when the countries are divided into two groups according to the 0 ordinate; A statistically significant difference was found between the two groups in terms of mortality rates due to infectious and parasitic diseases, prostate cancer and neurological diseases (Table 4, Fig. 4).

\section{DISCUSSION}

MDS, which is used to visually reveal the relationships between objects or units in a less dimensional space; it can be applied on various data types measured with ordinal, evenly spaced, proportional scale and is widely used $[18,19]$.

This study was carried out by taking into account the age-standardized mortality rates per 100,000 population according to the GHE categories of the European Union member and candidate countries. In this study, a MDS analysis was carried out in order to understand which variables caused the distinction between European Union member countries and candidate countries. As a result of examining the literature on the subject among 31 European Union member and candidate countries (Montenegro could not be included in the study due to lack of data), 41 variables were included in the analysis by considering a standard classification criterion for disease-specific mortality rates.

In the first dimension, countries, especially in terms of other cancer types except prostate cancer, in the second dimension, it is seen that it differs especially in terms of moratality rates due to infectious and parasitic diseases and prostate cancer. For both dimensions, the countries of Germany, Austria, Belgium, Czechia, Denmark, France, Croatia, Netherlands, Ireland, Spain, Sweden, Italy, Cyprus, Luxembourg, Malta, Portugal, Slovenia, Greece formed a close group and Turkey's were found to be close to these countries in both groups. In the first group, especially Albania, Macedonia and Bulgaria, Serbia, Latvia, Romania, Lithuania and Hungary differ from other countries, in the second group, it is seen that especially Finland, Albania and Slovakia differ from other countries.

As can be seen from Fig. 3 in the first dimension of the GSE categories, our country differed from countries with high rates of colon rectum cancer, especially Slovakia and Hungary, and it was observed that it got closer to countries with low mortality rates. As can be seen from Fig. 4 in the first dimension of the GSE categories, our country differs from countries such as Bulgaria and Macedonia with high rates of cardiovascular diseases. As can be seen from Fig. 5 in the second dimension of the GSE categories, our country differs from countries with high rates of infectious and parasitic diseases, such as Greece and Romania, and converges with countries with low mortality rates.

\section{CONCLUSION}

The solution of health problems has been one of the important and determining factors in every age, the goal of people to live a modern, contemporary and prosperous life. It would be beneficial to determine the standardized mortality rates according to GHE by comparing them with European Union member states and to carry out studies to solve them by taking into account the negative aspects.

\section{Authors' Contribution}

Study Conception: DS, SK; Study Design: DS; Supervision: DS; Funding: DS; Materials: DS; Data Collection and/or Processing: DS; Statistical Analysis and/or Data Interpretation: SK; Literature Review: DS; Manuscript Preparation: DS, SK and Critical Review: DS, SK.

\section{Conflict of interest}

The authors disclosed no conflict of interest during the preparation or publication of this manuscript.

\section{Financing}

The authors disclosed that they did not receive any grant during conduction or writing of this study.

\section{REFERENCES}

1. WHO methods and data sources for country-level causes of death 2000-2019. (Global Health Estimates Technical Paper WHO/DDI/DNA/GHE/2020.2). Geneva, World Health Organization; 2020.

2. Global Health Estimates 2020: Deaths by Cause, Age, Sex, by 
Country and by Region, 2000-2019. Geneva, World Health Organization; 2020.

3. Yavuz Emik K, Önal AE. [The epidemiological study of death in Turkey between 2009-2016 and the importance of the death statement system]. J Ist Faculty Med 2019;82):149-55. [Article in Turkish]

4. Akturan S, Gümüş B, Özer Ö, Balandız H, Erenler AK. [Death Rates and Causes of Death in Turkey Between 2009 and 2016 Based on TUIK Data]. Konuralp Tip Dergisi 2019;11:9-16. [Article in Turkish]

5. Türkiye İstatistik Kurumu. Available at: www.tuik.gov.tr. Accessed May 13, 2021.

6. World Health Organization. WHO Mortality Database. Available at: http://www.who.int/healthinfo/statistics/mortality_rawdata/en/. Accessed May 13, 2021.

7. Sungur İ, Çöl M. [Situation of Mortality Related Important Indicators in the World and in Turkey]. Ankara Üniversitesi T1p Fakültesi Mecmuası 2016;69:1-6. [Article in Turkish]

8. Türkiye İstatistik Kurumu Ölüm ve Ölüm Nedeni İstatistikleri, 2019. Available at: https://data.tuik.gov.tr. Accessed May 13, 2021.

9. Nasraoui O, Ben N'Cir C-E (eds). Clustering Methods for Big Data Analytics. 1st edition. Springer Nature Switzerland, 2019. 10. Anderberg MR. Cluster Analysis for Applications. Academic Press: New York, 1973.

11. Alpar R.; Çok Değişkenli İstatistiksel Yöntemler, Detay Yayınc1lık, Ankara, 2011.

12. Horozoğlu Ö, Hallaç Y, Sığırlı D. [Examination of Turkey’s and European Union member states' health indicators with multidimensionel scaling]. Uludağ Üniversitesi Tıp Fakültesi Dergisi 2017;43:49-52. [Article in Turkish]

13. Özdamar K. Paket Programlarla İstatistiksel Veri Analizi 2, Kaan Kitabevi, Eskişehir, 1999.

14. Lilien GL, Rangaswamy A. Marketing Engineering: Computer Assited Marketing Analysis and Planning, Prentice Hall, New Jersey, 2003.

15. Rouzier R, Perou CM, Symmans WF, Ibrahim N, Cristofanilli
M, Anderson K, et al. Breast cancer molecular subtypes respond differently to preoperative chemotherapy. Clin Cancer Res 2005; 11:5678-85.

16. Mackay DB, Easley RF, Zinnes YL. A single ideal point model for market structure analysis. J Marketing Res 1995;32:433-43.

17. Kalaycı Ş. SPSS Uygulamalı Çok Değişkenli İstatistik Teknikleri, 4. Baskı, Asil Yayın Dağıtım, 2009.

18. Lorr M. Cluster Analysis for Social Scientists, Jossey-Bass Publishers, London, 1983.

19. Tatlıdil H. Uygulamalı Çok Değişkenli İstatistiksel Analiz, Cem Web Ofset, Ankara, 1996.

20. Kruskal, J. B., Multidimensional scaling by optimizing goodness of fit to a nonmetric hypothesis, Psychometrica 1964;29:127.

21. Mead A. Review of the development of multidimensional scaling methods. Statistician 1992;41:27-39.

22. Johnson RA, Wichern DW. Applied Multivariate Statistical Analysis, Prentice Hall, Upper Saddle River, New Jersey, USA, 1999.

23. Wilkermaier F. An introduction to MDS. Sound Quality Research Unit, 2003.

24. Everitt B, Dunn G. Applied Multivariate Data Analysis, Oxford Uni. Press, New York, 1992:101.

25. MacQueen JB. Some Methods For Classification and Analysis of Multivariate Observations. Proc. of the Fifth Berkeley Symp. on Mathematical Statistics and Probability. USA: Berkeley; 1967:281-97.

26. Nakip M. Pazarlama Araştırmaları: Teknikler ve (SPSS Destekli) Uygulamalar. Seçkin Yayıncılık, Ankara, 2003.

27. Çelik Ş. [Classification of provinces in Turkey in terms of livestock using multidimensional scaling analysis]. Erciyes Üniversitesi Fen Bilimleri Enstitüsü Dergisi 2015;31:159-64. [Article in Turkish]

28. Hair JF, Anderson RE, Tatham RL, eds. Multivariate Data Analysis With Readings. 2nd ed., Mcmillan Book Company: London, 2006. 